\title{
The Use of Action Songs in Developing Vocabulary among pupils of the rural area
}

\author{
Nurnadirah binti Khairul Annuar Asyaari ${ }^{[1][2]}$,Azlina Abdul Aziz ${ }^{[2][2]}$ \\ ${ }^{1}$ SK Nanga Oyan, D/A PPD Kapit, 96800 Kapit, Sarawak \\ ${ }^{2}$ Faculty of Education, Universiti Kebangsaan Malaysia (UKM), 43600 Bangi, Selangor, Malaysia
}

DOI: $10.29322 / \mathrm{IJSRP} .10 .02 .2020 . \mathrm{p} 9808$

http://dx.doi.org/10.29322/IJSRP.10.02.2020.p9808

\begin{abstract}
Pupils of the rural area particularly the level one pupils are lacking in English vocabulary. The objectives of this action research are, to improve the vocabulary of the level one pupils by using the intervention of Action Song and to identify how pupils perceived the effectiveness of the action songs in improving their vocabulary. This action research focused on 16 level one pupils of the native tribe (Iban) of a school in rural area of Kapit. The data are collected in the manner of triangulation of data which are the pre and post-test,observation, and interview. This research follows the Kemmis and McTanggart (1988) cyclic process of research. The finding shows that Action Songs helped in improving the pupils' vocabulary . The pupils retain the growth and improvement in their ability to identify and describe the vocabularies learned from the action songs by scoring higher in their post test compared to their pretest .
\end{abstract}

Index Terms- vocabulary,Action Song,pupils of rural area

\section{INTRODUCTION}

$\mathrm{E}$ nglish has been accommodated as one of the language spoken since the colonial time.English has also undergone through process of several language policies which has also affected the curriculum in the education as well. The implementation of several language policies of Upholding the Malay Language and Strengthening the English Language or most extensively known nation-wide as MBMMBI (Musa,2009), and then the implementation of PPSMI (pengajaran dan pembelajaran Sains dan Matematik dalam bahasa Inggeris ) The teaching and Learning of Science and Mathematics in English (Kepol,2017,p.187-209) was to address the issue of the declining performance of the English Subject at the level of schooling.Since then, English language learning and teaching has changed as a whole. The fundamental of English proficiency is a wide set of vocabulary. Until today,there are numerous teaching and learning method to improve vocabulary.

Vocabulary development is a course of human brain in attaining words (Definition, 2019). This process works effectively to the young learners when in an unconscious environment, in which the words are acquired naturally without being explicitly taught to them. Stephen Krashen (1982) proves this with the theory of the second language acquisition. Krashen's second language acquisition theory stated that the process of language learning is congruent with the way children perceived their first language. It is a subliminal process in which children unaware that they are acquiring the language (Krashen, 1982, p.10). English language is not the second language for the pupils of the rural area, conversing in English seems to be difficult to them. Having surrounded by community that do not speak the language the pupil's vocabulary development of the language become limited. Limited utterly to the level of vocabulary learned only during the English lesson. It is a problem for the pupils to be taught with four skills of speaking,listening,writing and reading with lack of basic vocabulary. Therefore,the intervention is an approach that is closer to the pupils which is singing and incorporated together with actions. 


\section{RESEARCH ELABORATIONS}

\section{A.Literature Review}

Vocabulary development is a course of human brain in attaining words (Definition, 2019). This process works effectively to the young learners when in an unconscious environment, in which the words are acquired naturally without being explicitly taught to them. Stephen Krashen (1982) proves this with the theory of the second language acquisition. Vocabulary is essential in order to be fluent in English. It acts as the foundation blocks to next level of English learning. It is without vocabularies one is unable to come up with words to compose a sentence. It is estimated that between 6000 to 7000 words should be known by the language learner and between 8000 to 9000 words should be known by a learner to be able to build well-written sentences (Lebedev,2019).

Another important discovery in English learning is that there is a great variety of vocabulary in the first 1000 words by the students, and these words cover 78 to 81 percent of the spoken texts (Lebedev,2019).Therefore, knowledge of vocabulary is considered a necessary component for understanding the simplest written texts (Yan, Goh \& Zhou 2018). For example, the English language curriculum practices followed in Malaysia demands the teachers to teach English language speaking in a communicative manner as reported by the study of Yan, Goh and Zhou (2018). It means that learning should be explored with high exposure for teaching and minimum exposure to written form.

The slow learners can face a significantly high number of issues in learning English lessons because they might not receive a high input. As for such, the study of Yan, Goh and Zhou (2018) argued that new information should be represented in a comprehensible manner for the learners so they can understand new words and process them accordingly. This factor is also a comprehensible way for the learners in understanding and grasping the concepts of English because they could not understand lessons with effectiveness especially when understanding the targeted language. In addition, most of the students are not aware of the importance of the English language and its importance in the context of international language (Hughes 2015). Due to which it causes them to be less motivated.

Mainly, vocabulary can be taught implicitly and explicitly. Language teachers are expected to learn and incorporate both of these implicit and explicit vocabulary learning methods within their lessons. However, Yan, Goh and Zhou (2018) argued that not many teachers have the knowledge and understanding of doing so in language classroom. Therefore, in order to learn new words, explicit learning activities should be used which are based on targeted words.This statement therefore direct the route to the idea of incorporating action song as an intervention in teaching vocabulary. Young learners are easy to be motivated with the right approaches. In this research the approach of the action song is chosen as the intervention. The nature of the pupils chosen for this research is,they are both bodily-kinesthetical and musically motivated types of learner. They enjoyed singing and dancing as part of their favourable activity in any lesson. It is shown through their engagement with the lesson when any teacher incorporated singing and dancing in the lesson.

Song has been known to be effective in implanting memory of the words in the lyrics,let alone to incorporate it with action. Action song is one of the language tool in teaching language. It is also included in the KSSR curriculum standard as one of the ability that can be achieved in the learning standard under the Language Arts skills. Action songs is mentioned in the standard of 5.1; Enjoy and appreciate rhymes, poems and songs, 5.1.1; iii) simple action songs (Kementerian Pelajaran Malaysia, 2010). In the area of where this research is conducted, action songs has been one of the most favourable activity among the pupils regardless of their gender. The tendency of songs being lyrically repetitive and have catchy melody which attract the pupils' interest making it effortless to be learned by young learners. Plus, language is naturally sustained in both structures and vocabulary (Clarke, 2012).In addition, pupils that are usually reserved would be able to be more confident and bold as action songs helps children to balance their emotions (Clarke,2012). Therefore, utilizing actions song is suitable to be used to expose the pupils with basic vocabulary.

\section{B.Methodology}

This research is qualitative in nature. This research is an action research and in the search to answer these research questions, they are, How does the use of the action songs help to develop young learner's vocabulary? and, How do young learners perceive the effectiveness of using action songs to develop vocabulary? This action research was conducted based on the Kemmis and McTaggart 
(2000) cyclic model.The action songs that are used in this research are originally written and words are chosen from the level one textbooks, and the words chosen are the words with high frequency amount of appearances in the sentences of the textbooks. The melody of the action songs follows the melody of famous nursery rhymes that are famous in the English teaching world.

The population chosen were all from the level 1 pupils with very low proficiency level,and 16 sample were chosen for data collection. The participants are all native Iban speaker and Malay language is their second language therefore English is their third language. With the only exposure to the first language being the conversation they have with the teachers during lesson, it can be concluded that the participants yet to even become fluent with the second language. The data were collected by using three instrument,pretest and post test, observation,and interview. The test were administered in two cycle,the pretest was conducted in the first cycle and the posttest was on the second cycle. The data for observation was collected and recorded throughout the intervention of the action song by using field note.They are introduced to ten songs in different days.The interview was done in group after the post test was conducted.

\section{C.Procedure}

This research was conducted within 12 weeks. The pretest was administered during the first cycle before the action song was introduced to them. The first cycle went on for seven weeks. The first three weeks was an introductory weeks for the pupils ,in which the pupils were introduced with all the ten songs. The pupils were introduced to the first three songs in the first week of the intervention,together with the actions.Another three songs were taught to them on the second week,and the other four songs were in the third week. Then the action songs were then practiced with them everyday for four weeks for observation data for the first cycle. The second cycle started off on the eighth week. Then the observation data was collected again for another four weeks. On the twelfth week,the post test was administered and followed by interview which was done in group. Example of the question of the test is shown in Figure 1.

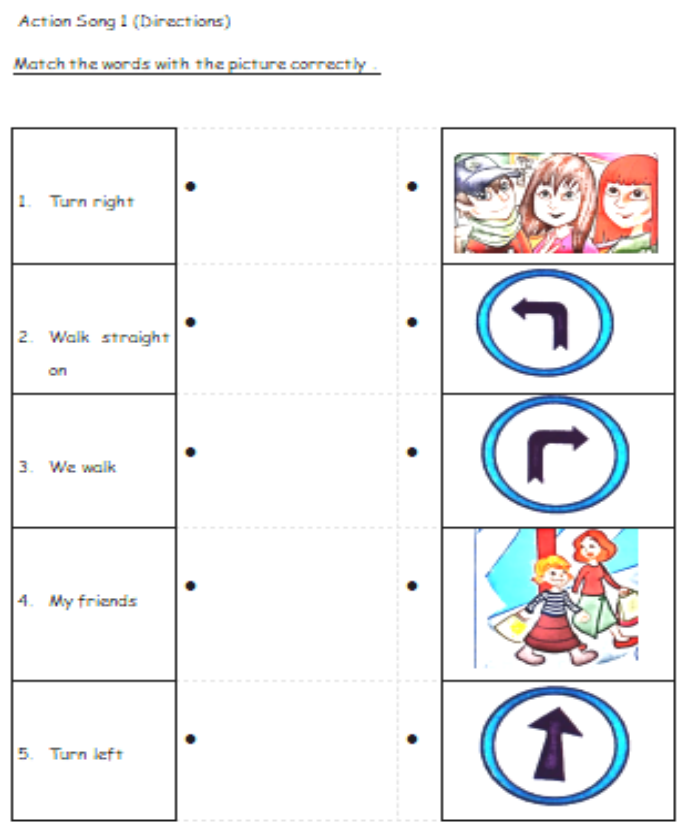

Figure 1.One type of question from the test. 
The questions for the pretest and post-test comprises of 99 questions on words of the vocabulary that pupils needed to be exposed with. The questions were tested on 115 words taught in the action song .

\section{FINDINGS AND DISCUSSION}

Central tendency of descriptive statistics is selected to analyse the mean of pretest and post-test score of the pupils test using Statistical Package of Social Sciences (SPSS) IBM 23. During administrating the test in the first cycle,the pupils were mainly just guessing the words based on their prior knowledge of the picture shown in the test. The amount of correct answer during the pretest was also merely luck as when being asked on how they manage answered some questions correctly, they said they were basically just matching the picture with any picture that they thought would make a nice pattern of line in the pages. It shows that they were even lacking the knowledge on most of the action of the cartoon in the picture of the test. The situation was far more different when they sat for the test for the second time. Several pupils even whispered to their friends that they have answered the test before and to them it would be easy during the second time they took it. They were right. Their pre-test score and their post-test score have a significant different. The distinct features of the pupils' score is showing that the pupils improved steadily. Table 1 shows the result of the pupils' pre-test and the post-test.

\begin{tabular}{|c|c|c|}
\hline Pupils & Pre-test & Post-test \\
\hline $\mathrm{P} 1$ & 17 & 65 \\
\hline $\mathrm{P} 2$ & 17 & 91 \\
\hline P3 & 13 & 91 \\
\hline P4 & 24 & 94 \\
\hline P5 & 10 & 79 \\
\hline P6 & 15 & 84 \\
\hline P7 & 20 & 76 \\
\hline P8 & 14 & 91 \\
\hline P9 & 25 & 97 \\
\hline P10 & 15 & 64 \\
\hline P11 & 12 & 41 \\
\hline $\mathrm{P} 12$ & 21 & 82 \\
\hline $\mathrm{P} 13$ & 30 & 95 \\
\hline P14 & 13 & 13 \\
\hline P15 & 10 & 58 \\
\hline P16 & 11 & 60 \\
\hline Total mean score & 16.69 & 73.81 \\
\hline
\end{tabular}

Table1.The Pre-test and Post-test score . 
The mean of the pretest was $M=16.69$ and the post-test was $M=73.81$ which was higher than the pretest . It shows a significant increase between the score of pretest and post-test which shows that the action song does improve the pupils vocabulary. As for the observation test, the pupils were able to sing seven songs out of ten songs perfectly with all the actions. As for the interview, the pupils frequently said "because I like to sing and dance",and also "I like to sing and dance because its fun", the themes for the interview were met and they were able to perceived the effectiveness of the action song by comparing their own test before and after they learn the songs. The action of the songs which they refer to as the dance moves was fun and easy to follow.Therefore,it was easy for them to remember the action after being repeatedly practiced with them for weeks.However,there were three songs that were considered the least to be their favourite. This was due to the less body action incorporated in the songs. It shows that the actions are important in a song to them. The action songs not only improved the pupils vocabulary but also their interest to be engaged during the intervention.

\section{CONCLUSION}

Once reflecting upon the results of all the findings,the intervention of the action songs indeed helps in improving the pupils vocabulary and the pupils were able to anticipate the changes about their improvement in learning English vocabulary,showing that they were able to see the effectiveness of the action songs.The action songs were already intriguing enough when it was being introduced to the pupils.Action song manage to excite the pupils to be engaged in the learning and had helped them to improve in acquiring more vocabularies one song after the other. For improvement on further research,this action song can be further made interesting with the accompany of music,as in this research the songs were sung without music. That would hope to maximize the effectiveness of action song in improving vocabulary.

\section{REFERENCES}

[1] Clarke, S. (2012). Kids and songs;British Council. https://www.teachingenglish.org.uk/article/kids-songs

[2] Definition. (2019). What does vocabulary development mean? . https://www.definitions.net/definition/vocabulary+development

[3] Hughes, G. (2015). An encyclopedia of swearing: The social history of oaths, profanity, foul language, and ethnic slurs in the English-speaking world. Routledge.

[4] Kepol, N. (2017). Quality Malaysian English Language Teachers: Examining a Policy Strategy. Malaysian Journal of Learning and Instruction, (Vol. 14, No. 1 June 2017), 187-209. doi:10.32890/mjli2017.14.1.8

[5] Kementerian Pelajaran Malaysia. (2011). Dokumen Standard Sekolah Rendah (KSSR) Bahasa Inggeris Sekolah Kebangsaan Tahun I dan 2 (1 st ed.). Putrajaya: Bahagian Pembangunan Kurikulum.

[6] Krashen, S. D. (1982). Principles and practice in second language acquisition (1st ed.). Pergamon Press Inc.

[7] Lebedev, J. R. (2019). English Vocabulary. https://www.usalearns.org/english-vocabulary

[8] Musa, N. (2009). Memartabatkan Bahasa Melayu, Memantapkan Bahasa Inggeris: Tawaran Baru Sistem Pendidikan Malaysia. https://www.moe.gov.my/index.php/2-uncategorised/4210-memartabatkan-bahasa-melayu-memantapkan-bahasa-inggeris-tawaran-baru-sistem-pendidikanmalaysia

\section{AUTHORS}

First Author - Nurnadirah binti Khairul Annuar Asya'ari, Master's Student (TESL), SK Nanga Oyan, Faculty of Education, Universiti Kebangsaan Malaysia, elotasyaari@gmail.com.

Second Author - Azlina Abdul Aziz, Faculty of Education, Universiti Kebangsaan Malaysia, azlina1@ukm.edu.my

Correspondence Author - Azlina Abdul Aziz, Faculty of Education, Universiti Kebangsaan Malaysia, azlina1@ukm.edu.my 